\title{
PROFESSIONAL FORMATION OF THE TEACHER AS A SOURCE OF PROFESSIONAL CAREER DEVELOPMENT
}

Dr. Kekeeva Z. Ochirovna, Federal state budgetary educational institution of higher education "Kalmyk State University named after B. B. Gorodovikov", Russian Federation

E-mail: kekeeva-zo@yandex.ru

Dr. Sherayzina R. M Moiseyevna, Federal state budgetary educational institution of higher education "Novgorod State University named after Yaroslav the Wise", Russian Federation

E-mail: roza.sherayzina@novsu.ru

ARTICLE INFO

Studies and Articles

Received: March, 13.2016.

Revised: April, 27.2016.

Accepted: May, 01.2016.

doi:10.5937/IJCRSEE1601073O

UDK

$371.12 / .13(470)$

371.12:159.923.3(470)

\section{Keywords: \\ traditions,}

ethnicity,

teacher,

university,

behavior,

modernization,

career,

identity,

formation.

\section{A B S T R A C T}

The article deals with the problem of professional formation of the teacher as a source of professional career development. The authors reveal the role of professional teacher's conduct in the process of cognition students' cultural values of their ethnic group, the moral values of human conduct in the ethnocultural environment of the region. The authors also provide the basis for the process of professional formation of the future teacher as a source of professional career development in the self-development of cultural and educational space of the university in the region.

(C) 2016 IJCRSEE. All rights reserved.

\section{INTRODUCTION}

Innovative changes happening at the beginning of the XXI century brought radical changes in the traditional system of education in the era of information and globalization. That contributed to the diversification of educational systems and the emergence of multiple educational routes in the content of education development strategy. In this regard, there is a rethinking of the individual teacher role in the area of upbringing and education. In the new system, the question of the professional teacher training and the content of teacher education is put on the new. The personality of the teacher, his professional competence, so-

Corresponding Author

Dr. Kekeeva Z. Ochirovna, Federal state budgetary educational institution of higher education "Kalmyk State University named after B. B. Gorodovikov", Russian Federation, E-mail: kekeeva-zo@yandex.ru

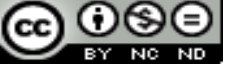

This work is licensed under a Creative Commons Attribution 4.0 International license. The article is published with Open Access at www.ijcrsee.com cial maturity and spiritual wealth contribute to improving the quality and effectiveness of the training process in high school.

However, in terms of modernization in education sphere, there are some contradictions between the fundamental features of teacher education system in forming the developing personality and relatively inefficient use of the process of designing the content of teacher education at the present stage of reconstruction of the whole society in the educational space. It is also necessary to study the potential of developing educational space Regional University in the professional development of the teacher in a multicultural environment and at the same time, there is a lack of scientific basis for the implementation this idea in making a socio-qualification career.

Today, teacher education in the educational space of the university is a systemforming factor of a new educational model and it allows us to consider the formation of professional and personal competence of the teacher in the context of ethnic and cultural characteristics of the region.

Educational space of the university in the region is an objective reality of the territorial 
educational system, which is a set of material, political, ideological and socio-psychological factors, interacting directly with the personality of the teacher in the course of vocational training in high school.

The technique of writing this article was to review the process of professional formation of the future teacher in the socio-cultural environment of the region, assimilating ethnic and cultural traditions, way of life and mentality of the people, the future of students and their parents in the educational space of the university as a source of social development and qualification of the teacher's career. During the transition to the regional economy to an innovative model of development of basic industries, ensuring its growth, are science and education. The teacher of high level, being professionally successful, ensures the unity of science, culture and education. This unity is the main resource for the development of quality of life in the region. The lack of qualified, professionally trained teachers, motivated for individual personal advancement in the territorial educational system considerably hampers innovation processes in the economy and in the socio-cultural sphere, indicating a need for the development of pedagogical forecasting skills.

Researcher Sherayzina R. M. notes that pedagogical forecasting is a scientific activity, based on a specially arranged complex of research aimed at identifying possible changes, trends, and prospects of development of the subjects and objects of pedagogical activity, which allows obtaining reliable advance information about their development in innovation activity.

Innovative activity is focused on creating the conditions and set up for success in any field of their possible applications. Innovative trends in vocational training motivate changes in the educational process in a high educational institution in the following areas: a change of goal-setting; formation of a new educational content, which is close to the rapidly changing life and which contributes to the preservation of the fundamentals; development and implementation of new educational programs on the basis of competence approach, taking into account the diversity of cultures, readiness for intercultural interaction in the conditions of development of modern civilization.

Modernization of education, according to R. M. Sherayzina, dictates the need for a transition from the traditional professional paradigm to the innovative one (Musin-Maznov G. H., 2016).
Table 1. Changing of traditional professional paradigm to the innovative paradigm in the modernization of education

\begin{tabular}{llll}
\hline № & Criteria & $\begin{array}{l}\text { Traditional } \\
\text { paradigm }\end{array}$ & $\begin{array}{l}\text { Innovative } \\
\text { paradigm }\end{array}$ \\
\hline 1. & Position & $\begin{array}{l}\text { Stability, } \\
\text { rationality }\end{array}$ & $\begin{array}{l}\text { Change, } \\
\text { solution }\end{array}$ \\
\hline 2. & Technologies & Mechanical & electronic \\
\hline 3. & Career goals & $\begin{array}{l}\text { Safety, } \\
\text { reliability, } \\
\text { security }\end{array}$ & $\begin{array}{l}\text { Personal } \\
\text { growth, } \\
\text { excellence }\end{array}$ \\
\hline 4. & Leadership & Autocratical & Transformative \\
\hline 5. & $\begin{array}{l}\text { Completing } \\
\text { quests }\end{array}$ & Individual & Team \\
\hline 6. & Resources & Capital & Information \\
\hline
\end{tabular}

Competence approach to the formation of ethnic identity, in our opinion, will help the teacher, not only to adequately act in the current intercultural environment but also to be prepared to change it, be prepared for self-restructuring their own educational activities, if required by changed conditions of life.

Gargay, V. B. highlights the fact that at the present stage, the teacher training is becoming more meaningful process running inside the learner, and departs from the understanding of the training as a set of some usual actions of teachers, suitable for any pedagogical situation (Gargay, V. B., 2005).

Researcher D. Tripp suggested using the technique of "Path of Life" in the development of the professional identity of the teacher as a form of gestalt, which is in the picture of the timeline, where future teachers celebrate important events and people who have an impact on their professional development. Students' awareness of their gestalt in assessing the positive and negative school teacher behaviors creates an image of the ideal teacher. This is what they would like to be themselves; it promotes the formation of students' professional identity in their pedagogical activity (Tripp D., 1994). From the point of view of the researcher F. Korthagen, calling in teacher's behavior model is based on the foundation qualities of the translation technique of their personality in a particular behavior in a given situation (Korthagen, F. A., 2004). The educational activity, as a special kind of social reality in the educational space of the university, is aimed at the development of educational content, the development of subject-subject interaction of the teacher with the students in a specially organized process of learning. It is done in order to create conditions for the development of professional identity of teachers and training them to perform certain social roles various ethnic communities. Today, young teachers 
are in dire need for social guidelines, based on national values of universal orientation in their professional education. Ethno-cultural traditions arose teachers' genetic memory, actualize continuity in the pedagogical environment, and greatly increase the essence of the "Ego" in their professional formation. Researcher R. Bullough notes that teacher's education begins with an understanding of the essence of the "Ego". This self-concept of a future teacher is the foundation without which all further practical and theoretical structures are meaningless (Bullough, R. V.,1997). The construction of educational process on ethnic cultural traditions gives it a humanistic nature; it promotes the formation of value orientations, moral and spiritual stability, and civilpatriotic position of ethnic identity.

\section{MAIN PART}

The personality of a teacher, his professional competence, social maturity and spiritual wealth are now the most important factors in the development of ethnic self-awareness among the younger generation.

The need for this is particularly increasing in the period of Russia's entry into the twenty-first century, which has set the task of building a new school, and "growing up" the generation of teachers capable of creation, creativity, the author's approach in solving professional problems. With the rise of antisocial negative phenomena in the youth environment and rethinking the value orientations in the context of global changes in society, the requirements for the professional competence of teachers are becoming stronger. It deals with the content and technology of teacher education: knowledge, skills, methods of pedagogical activity, their willingness to address unusual situations, and challenges in the changing world.

In this connection, the existing education system must have adequate resources to assist students in building a successful socialqualifying career in accordance with their national and gender peculiarities. Professional self-determination in building the personality of the teacher in their career is due to the change in the nature and content of the professional activity and its behavior. It shows that during the period of the country's transition to the market economy conditions the formation of a future teacher's competence, the career development is one of the urgent problems of the competitiveness of human resources in the process of professional development. Improving teachers' competitiveness in the labor market provides a comprehensive development of the economy and national security of the state. According to M. V. Aleksandrova, teacher's career is a "conscious attitude to their own motion in the steps of professional development that characterizes the levels of achievement in various activities (professional, managerial, social, etc.). And it involves the increase of the status in the social and educational environment" (Aleksandrova, M. V., 2007).

The difficulty of professional self-determination and the construction of the future teacher professional career in the contemporary Russian society is confirmed by numerous studies. In the pedagogical science is no longer identified the concept of "professional self-determination" and "career choice". The professional self-determination is now being studied as a holistic personal formation of a professional career. These changes are not baseless. Indeed, the continuous nature of professional self-determination is not only dictated by the needs of a constantly evolving personality, but also the modern social conditions, when a young person is forced to change the scope of its activities and is also associated with changes in the nature and content of the most professional work. The transition of the country to the market economic conditions puts the competitiveness of human resources on one of the most important places. In these circumstances, a person is an active subject in the labor market, having the ability to freely dispose of their primary capital - qualifications. In conjunction with the freedom to choose the person sphere of professional activity, it gives them the opportunity to build a successful professional career.

However, the results of studies carried out by M. V. Aleksandrova showed that out of 1,000 respondents who were educational workers, only $17 \%$ of teachers consider their career as promotion through the ranks, and $40 \%$ - as the professional growth without linking this process with the official hierarchy. At the same time, $57 \%$ of teachers indicate a connection of their career with a good salary, recognition of students, and achievement of high social status. For $25 \%$ of respondents, a career is a personal self-realization, self-assertion, the satisfaction of their own ambitions. However, more than half of the teachers surveyed $(58 \%)$ do not plan their own career, $23 \%$ of teachers are quite satisfied with their own career development, $79 \%$ of them are considering a career just as the promotion of the career 
ladder, almost $37 \%$ of the educational workers explain their refusal to work in their specialty in education system with the inability of successful career.

These findings suggest that teachers have some intuitive idea of a career, and for students the lack of information about career opportunities in the education system is one of the reasons for their employment not in the pedagogical fields (Aleksandrova, M. V., 2007)

Particular importance in today's multicultural society is the individual's ability to design their social-qualifying career. As researchers S. A. Trashchenkova, M. V. Aleksandrova and R. M. Sherayzina note this type of career may be considered "as a universal form of movement and human development, a focused continuous process and integrative quality of social systems".

Within the context of our study, it is important to determine the nature of social and qualifying teacher's career, which the authors defined as "a complex characteristic of their successful professional and social development of a chain of individual achievements of the teacher having an impact on the formation of the person of a particular teacher, contributing to the formation of their artistic personality, enhance social and qualifying status in the region. The levels of formation a socialqualifying career are: qualifying (pedagogical skills, the recognition by educational communities, authority in a particular form of educational activity), qualifying and social (leadership in the interdisciplinary field, authority in professional pedagogical community), social and qualifying (leadership in public social field, in the territorial authority of the community)" (Aleksandrova M.V., Trashchenkova S.A., Sherayzina R. M., 2014).

The effectiveness of the process of becoming a social-qualifying teacher's career is determined by the level of its social and educational activity, which is defined as the quality of the person. It appears in the activityvigorous open nature of the teacher, as well as in the ability to arouse active social and educational activities of other members. It is also characterized by the level of their professional identity, demonstration of subjectivity in social introspection of their professional achievements and social status.

However, in the old days, the crafts were the sign of the welfare of the country and its general level of culture. The mastery of arts and crafts was a socially necessary activity which was gradually developing into a hu- man profession. Professional experience in the work of folk masters was formed by the opening of the most effective methods and techniques of processing the material, bringing design skills to perfection. This experience was accumulated for centuries, handed down from generation to generation. Folk traditions and customs were the regulators of master's behavior who was a professional in their craft. This helped in the formation of value orientations of the individual, in the choice of examples, in the planning prospects in life. To a certain extent, it was the personality of the master influenced on the future generation that will be brought up, and what that generation would bring to the mankind in the future.

The behavior of the master of folk handicrafts is an important part of national culture, and this behavior causes the mechanism of ethnic identification. Features of peoples' mentality create a system of unique behavioral forms. Ethnic "I - concept" consists of several blocks: ethnical-psychological, anthropological, and social-genetic. The ethnic "I - image" is kept in the minds of people, in cultural monuments, religious traditions, moral norms, rituals, etc. In their studies, V. Yu. Khotinets and A. I. Troyanskaya noted that the ethnic identity is closely integrated into the structure of the professional reflection of the person in the final stage of professionalization.

In this connection, from 2008 to 2014 in the Republic of Kalmykia of the Russian Federation, there was carried out the experimental work on the study of the integration features of teachers' professional development with innovative social and educational processes in the self-development of cultural and educational space of the university in the region. The experimental work was attended by 140 students by specialty "Pedagogical Education" (Bachelor - Master), "Biology" (Bachelor) of Kalmyk State University and 70 students from the school of Khar Buluk Village of Tselinniy District of Kalmyk Republic under the leadership of the school principal, Honorable worker of the general education of the Russian Federation T. V. Lidzhieva.

Khar Buluk village with its suburbs is one of the historical places of Kalmykia with healing springs, Buddhist monuments of culture, and folk traditions. The process of familiarizing students to the knowledge of the values of the national culture in the content of the work was carried out on the basis of ecological and ethnographic club "Hope" for students of 4-11 grades of school settlement Khar Buluk, Tselinniy district of the Republic 
of Kalmykia. This club is headed and directed by an Honored Teacher of the Russian Federation Lidzhieva I. G.

Academic and extracurricular activities at the club were organized in four directions: "Nature and Culture", "The history of the native land", "Environmental ambulances", "Pedagogical culture of the teacher". The work of students' scientific society was carried out with the active involvement of the teachers of the department of the Russian language and literature ("Stylistics", "Seeker" section); mathematics and physics (section "Theoretical Physics", "Computer Science"); Social Sciences (section "Regional studies", "Culture of the peoples of the Volga region"); natural geographical sciences (section "Inorganic Chemistry", "Biology", "Physical geography"); Pedagogy and Psychology (section "Social Psychology", "Health Psychology"); Foreign languages (section "English") of Kalmyk State University.

Students of ecological-ethnographic club "Hope" and the teachers investigated water sources of the village, natural and artificial ecosystem, held monitoring of ecological state of the village, collected ethnographic material about folk healers of the region They also studied the history of his native school and the teachers' contribution to the development of the education system of Kalmykia, culture and ethnography of the Kalmyk people, folk traditions of a healthy lifestyle, forming valeologist culture. They started to secure the historic monument of national importance "A lonely popular in the steppe with a cascade of healing springs". Every year, the students of the school of Khar Buluk village of the Kalmyk Republic are taking part in competitions, environmental gatherings, and in all-Russian contests "My Little Motherland", "Fatherland", "The Man in history", "Russia - XX Century". Young people also joined in educational and research ecological projects "The Man on the Earth", "The problems of natural ecosystems", the Republican tourist and local history competitions "The Memorials of Russia", scientific and practical conferences (Kekeeva, Z. O., 2009). The professional behavior of a teacher contributed to the knowledge of the students' cultural values of their ethnic group, the moral values of human conduct in the ethnical-cultural environment. The teacher was their guide in the world of moral values of human behavior. According to J. Tomlinson, moral values are human code of conduct, which are based on the following ethical principles:

- rationality, independence of action and judgment, respect for professional knowledge, skills and experience;

- interests of students, maintenance of equality of educational opportunities;

- recognition of the teacher's right to an error, the development of partnership and the training of students in the educational process (Tomlinson, J., 2000). The analysis of the experimental work showed that future teachers $(52 \%)$ have become to feel more comfortable, more confident and more positively assess their capabilities. There is the increase of cognitive activity and creative independence, responsibility, the change of their attitude to the profession (Kekeeva, Z. O., 2009).

The organization of pedagogical activity of a future teacher in the educational space of the university contributed to familiarizing students to the knowledge of the values of culture and education in the region, and turning a pupil into the subject of the development of a competent personally important values of life in the area of culture and education in the region. The essence of pedagogical professionalism of the teacher lies in taking responsibility for the implementation of the action, based on theoretical knowledge, training, experience, and intuition.

The function of the pedagogical activity of a future teacher in the educational space of the university consisted in the formation of students' active position of the subject in the assimilation of culture and education in an ethnic and cultural environment of the region in designing a professional career.

\section{CONCLUSION}

Teachers' professional development is a source of social-qualifying career. In solving available problems a primary role plays ethnic and cultural identity in the formation of the professional experience of the teacher in pedagogical activity. The development of the valuable attitude of a future teacher to pedagogical activity was carried out through the knowledge of the values of culture and education in the region, development of active teaching positions in the preservation and development of spiritual culture, the development of interethnic dialogue and stability in the region. 


\section{ACKNOWLEDGMENTS}

We are grateful to our colleagues who are not authors of the article but assisted a lot T. N. Aksenova, S. V. Darzhinova, M. V. Aleksandrova, S. A. Trashchenkova.

\section{Conflict of interests}

The authors declare no conflict of interest.

\section{REFERENCES}

Aleksandrova, M. V. (2007). Support of the teachers in their careers of territorial educational system [Monograph]. Novgorod State University after Yaroslave the Wise. - Velikiy Novgorod.

Bullough, R. V. (1997). Practicing theory and theorizing practice in teacher education. Teaching about teaching: Purpose, passion and pedagogy in teacher education, 13-31.

Aleksandrova, M.V., Trashchenkova, S.A., \& Sherayzina, R.M. (2014). Formation of socioal and qualifying teacher's career. Velikiy Novgorod.

Gargay, V. B. (2005). The professional development of teachers in the West: a behavioral approach. Pedagogy No.6, 94 - 103.

Kekeeva, Z. O. (2009). Training teachers in cultural and educational space of the University: theory, methodology, practice [Monograph]. Volgograd: Publishing house of the Volgograd State Pedagogical University "Change".

Musina-Maznova, G. H. (2016). Formation of career orientations of future social employees in the process of two levels [Monograph]. M.: KNORUS; Astrakhan: ASU, publishing house "Astrakhan University".

Khotinets, V. Y., \& Troyanskaya, A. I. (2011). Ethnic and cultural peculiarities of professional reflection. Psikhologicheskii Zhurnal, 32(3), 57-73.

Korthagen, F. A. (2004). In search of the essence of a good teacher: Towards a more holistic approach in teacher education. Teaching and teacher education, 20(1), 77-97.

Tomlinson, J. (2000). Ethical Principles for the teaching profession. Report of UCET Working Party Occasional paper № 7 . London.

Tripp, D. (1994). Teachers 'lives, critical incidents, and professional practice. Qualitative Studies in education, 7(1), 65-76. 